\title{
Colonialism and its legacies, as reflected in water, incorporating a view from Malawi
}

\author{
Chandana Mathur $^{1}$ | Wapulumuka Mulwafu ${ }^{2}$
}

${ }^{1}$ Department of Anthropology, National

University of Ireland, Maynooth, Ireland

${ }^{2}$ Department of History, Chancellor College,

University of Malawi, Zomba, Malawi

Correspondence

Chandana Mathur, Department of Anthropology, National University of Ireland, Maynooth, County Kildare, Ireland.

Email: chandana.mathur@mu.ie
Continued, accelerating water inequalities and conflicts in the postcolonial world cannot be properly grasped without a thorough understanding of colonialism and its legacies. At the same time, water as a resource provides an immensely useful lens for understanding the intricacies and the dynamics of the colonial and postcolonial eras, in general terms, and in the particular historical instance of Malawi examined here. This essay draws on a range of literatures-social theory, political ecology, history, anthropology, sociology, geography, and so on-to demonstrate that struggles over water and other natural resources in the postcolonial world are situated within wider global structures and relationships of power. Starting with a discussion of theoretical approaches to water, the essay goes on to examine the processes of state formation in Sub-Saharan Africa, and explore the intersectionality of the contemporary lived experience of class, gender, race, and ethnicity in this region. It ends with a consideration of social differentiation, land tenure, degradation of water resources and natural resource conflict in Malawi. Traversing across humanities and social science disciplines, this essay uses water as a means of cutting a path through world historical questions on the articulations between the global and the local in the present era.

This article is categorized under:

Human Water $>$ Water Governance

Human Water $>$ Water as Imagined and Represented

\section{KEYWORDS}

capitalism, colonialism, environmental history, inequality, Malawi, postcolonial, power, resource conflict, sociocultural anthropology, Sub-Saharan Africa, water poverty

\section{1 | INTRODUCTION}

The basic premise of this essay is that continued, accelerating water inequalities and everyday struggles over water use in the postcolonial world cannot be properly grasped without a thorough understanding of the age of empire and the debris that it has left behind. At the same time, water provides an immensely useful lens for understanding the intricacies and the dynamics of the colonial and postcolonial eras, both in general terms, and in the particular historical instance of Malawi that we have examined in some detail. To adequately substantiate these assertions, we intend to chart here an ambitious, though by no means exhaustive, course across the humanities and social science literatures, engaging with the work of social theorists, political scientists, geographers, sociologists, and others, as well as that of our fellow anthropologists and historians. We begin with theoretical writings on colonialism and on water before delving into the histories of state formation in SubSaharan Africa. The complex intersections between class, race, and gender provide the next stopping point. The final three sections will draw significantly on the specific history of the colonial and postcolonial eras in Malawi. It is our hope that our 
reading of these literatures will open up a fuller view of the ways in which struggles over water and other natural resources in the postcolonial world continue to be situated within wider global structures and relationships of power.

Any deliberations on these issues must begin with a recognition of "the injustice of water poverty," as the geographer Alex Loftus terms it, in his discussion of the important recent work done by scholars using political ecology perspectives.

"Rather than taking it as a given that some will have access to water and others will not, or rather than finding solace in technical solutions or high-profile pledges, political ecology seeks to politicise understandings of the distribution of water. ...( Political ecologists) are against Malthusian readings of resource wars that naturalise the scarcity of resources, arguing instead for a recognition of the power relations through which resources are both produced and distributed" (Loftus, 2009: 953-954).

Political ecological studies of water (found in such works as Bryant \& Bailey, 1997, Donahue \& Johnston, 1997, Johnston, 2003, Peet \& Watts, 2004, Peet, Robbins, \& Watts, 2010, among others) have been hearteningly influential, significantly informing, for example, the first Human Development Report on access to water, titled Beyond Scarcity: Power, Poverty and the Global Water Crisis (United Nations Development Programme [UNDP], 2006). Sharing these concerns, this essay will reflect on some of the recurrent themes and key debates across a variety of literatures-delving into social theory, historical studies, ethnographic writings, and so on-regarding the structures and relationships of power that underlie water inequality in the postcolonial world.

In the context of this broad-stroke historical account of the relationship between nature, society and power, we recognize the continuities and congruence between water and other natural resources. Yet we will also need to be mindful of the critical differences between water and other natural resources, and indeed between different kinds of water resources and water flows. Take, for example, the difference between two types of water resources- the blue water resource in aquifers, lakes, and dams, and the green water resource intercepted by vegetation or entering as moisture in the soil. The water flows associated with them are also of two distinct types - the liquid blue water flow through rivers and aquifers and the green vapor water flow back to the atmosphere. The duality that we mention—of the interconnectedness between water and other resources on the one hand, and of the distinctiveness of water as a resource on the other-emerges powerfully in studies of water grabbing (Franco, Mehta, \& Veldwisch, 2013; Mehta, Veldwisch, \& Franco, 2012). Thinking in terms of the distinction between blue water and green water, blue water can be reallocated through conventional engineering means, but green water can be manipulated only through changes in land use. Thus, while it may be an enormous analytical mistake to lump land grabs and water grabs together in the one case, it may be just as crucial that they are understood as a single process in the other.

\section{2 | THEORETICAL POINTS OF DEPARTURE}

The emergence of global mass poverty is widely understood to be correlated with the histories and geographies of capital and empire. Drawing on the key insight of political ecology that global poverty, inequality and powerlessness usually underlie water poverty, we will have to revisit understandings of the historical rise and spread of world capitalism in order to grasp water poverty as it exists today. Rosa Luxemburg was one of the first theorists to suggest that capitalism can thrive alongside noncapitalist production relations elsewhere, and may indeed need them in order to survive (Luxemburg, 1913 [2003]). Her account of the predilection of the capitalist mode to expand overseas in search of cheap raw materials, cheap (and often unfree) labor, and new markets shows an early understanding of the economic underpinnings of imperialism. Where Marx had spoken of "primitive accumulation" (or direct plunder) during the era of mercantile adventure preceding the establishment of the capitalist mode of production, she conceived of "primitive accumulation" as an ongoing strategy of capitalism. ${ }^{1}$

David Harvey's articulation of contemporary capitalism's restless need for a "spatial fix" and of its strategy of "accumulation through dispossession" in new realms refers back to Luxemburg's insights (Harvey, 1982). More recently, Harvey and others have characterized the privatized provision of safe drinking water as a new form of "accumulation through dispossession" (Harvey, 2003; Swyngedouw, 2003). While it is important to situate water privatization within larger processes of capital accumulation, it is also necessary to note that privatization did not become as pervasive under neoliberalism as was initially feared, and that its consequences have not always been clear-cut (Loftus, 2009). Bakker's work is particularly useful in this regard-she argues that water is an "uncooperative commodity," not well suited to marketization, and that the "retreat of the state" in water provision may very well lead on to the "retreat of the market" in due course (Bakker, 2004).

The quite specific character of water as a resource, as a commodity and as a source of social connection has also been of interest to certain branches of anthropological thinking, as Ben Orlove and Steve Caton have shown in their comprehensive

\footnotetext{
1"Primitive accumulation" in the sub-Saharan African context meant, in the first instance, the transatlantic slave trade (Davidson, 1980, Mintz, 1985, etc.). Later eras have focused on the extraction of other resources from Africa (e.g., Arrighi et al., 2010; Carmody, 2011; Pakenham, 1991).
} 
review of the field (Orlove \& Caton, 2010). Thus, Veronica Strang takes note of the "essentiality" of water, or its centrality in multiple social domains (Strang, 2004; Strang, 2009). Kirsten Hastrup evokes "waterworlds" to consider the ways in which water makes and unmakes social worlds (Hastrup \& Hastrup, 2015). Orlove and Caton themselves underscore the distinctive "materiality" of water as well as its "connectivity," and conclude their review essay with the exhortation that water research should reach across to science and technology studies.

"waterworlds must be studied ethnographically, in all their components, including the often-neglected waterscapes..." (the term 'waterscapes' stresses the ideological and cultural-political dimensions of place, as used by such scholars as Swyngedouw, Baviskar, and others. "The wide range of people, agencies, and processes involved in addressing concrete water problems all require sustained scrutiny. Too often in the past, water consumers have been the sole concern, along with their national governments; this mindset is no longer sufficient when one realizes the profound presence and involvement of the transnational community of water experts" (Orlove \& Caton, 2010: 411).

The implication, of course, is that "water experts" must themselves/ourselves be scrutinized for the full explication of any given waterscape.

\section{3 | PROCESSES OF STATE FORMATION}

To understand current struggles over water in the postcolonial world, it is necessary to piece together the kind of "analytic history... needed to search out the causes of the present in the past", viz. "a historically oriented political economy" (Wolf, 1982: ix). Following on from Karl Wittfogel's formulation regarding the hydraulic basis of state power (Wittfogel, 1957), it is fitting to begin with writings that have engaged with the dynamics of state formation.

In attempting to understand how power is organized in contemporary African states and how it continues to successfully fragment resistance, the Ugandan scholar Mahmood Mamdani's classic Citizen and Subject proposes what amounts to a general theory of colonialism in Africa (Mamdani, 1996). He suggests that the various European colonial powers dealt with "the native question"- the question of how a relatively small group of colonialists can establish stable rule over an indigenous majority - in much the same way across the African continent. Thus, a bifurcated colonial state became the norm in Africa. There was direct rule and a racialized discourse of civil society in the urban context (to be a "citizen," one had to be European); and indirect rule, or "decentralized despotism" as he terms it, in rural areas, where the African population was purposefully splintered into different ethnic (and/or "tribal") groupings, and lived as "subjects" of so-called customary authority. Mamdani thus rejects the notion of South African exceptionalism, asserting that apartheid was the generic form of the colonial state in Africa. Noting that the British seemed to be particularly gifted at spotting "authoritarian possibilities in culture" (Mamdani, 1996:49), he shows how the colonial idea of custom was implanted across the continent (occasionally with chiefdoms being invented in erstwhile stateless societies), and the resulting "containerisation" of subject populations. It is an important argument about repurposing "the invention of tradition" (Hobsbawm \& Ranger, 1984; Southall, 1970) in the service of colonial governance. Mamdani says of the colonial project in Africa- "it has sold to the colonised its own notion of what was authentic about them, what was trans-historical about them, and what cannot be changed without being violated" (Naqvi \& Mathur, 2001:25).

This was a form of rule that managed to powerfully shape even the resistance that it spawned. Mamdani observes that the processes of decolonization were able to achieve deracialization but not democratization- the bifurcated colonial state was thus dismantled only partially — and tensions have continued between "containerised" ethnicities, and between rural and urban populations. He makes his argument using historical data from all across the African continent, but with particularly close attention to rural resistance movements in Uganda and urban resistance movements in South Africa.

The consequences of this form of rule were momentous throughout Africa. For instance, Mamdani uses the work of legal anthropologist Martin Chanock in Malawi and Zambia to show that the colonial state's sponsorship of customary law rendered women doubly subject, to male domination as well as colonial domination (Chanock, 1985). He also uses the work of Audrey Richards ${ }^{2}$ to show the rise of colonial era ethnic tensions in central Uganda ${ }^{3}$ (Richards, 1954). His own analyses of peasant movements in Uganda and of migrant workers in South Africa together form the backbone of his argument about the fragmentation of resistance in postcolonial Africa.

${ }^{2}$ For an evaluation of Richards, and hence an account of the mutual distrust between anthropologists (particularly women anthropologists) and colonial authorities in one particular historical circumstance, see David Mills' fascinating essay (Mills, 2006).

${ }^{3}$ Richards describes in detail the difficult road to assimilation into Ganda society for immigrants, for example, from Ruanda-Urundi (Richards, 1954:172). 
Commentators from multiple disciplines have seen the long shadow cast by colonial indirect rule in contemporary strategies and dilemmas of development (e.g., Berry, 1992; Cooke, 2003; Mizuno \& Okazawa, 2009; WaMuiu, 2010). As for natural resources, and specifically water, there were, of course, plentiful instances of the colonial appropriation of water. "In South Africa, settler farms were often named after the captured fountains-Grootfontein, Brakfontein, Modderfonteinwhich initially sustained them. By the mid-eighteenth century, as the trekboers moved into the dry interior of South Africa, nearly 50 percent of new farm names were water-related" (Guelke \& Shell, 1992). Equally, there was colonial conservationism. In a wide-ranging review essay on the intermeshing of colonial and postcolonial histories with the history of the environment in Africa, Beinart shows, drawing on the work of scholars such as Grove (Grove, 1995), that ecological and social regulation has usually gone hand in hand (Beinart, 2000). To cite a prominent example, Jan Christian Smuts simultaneously embraced ecological holism and racial hierarchy; he was at once a forward thinking conservationist and the retrograde architect of apartheid (Foster \& Clark, 2008). ${ }^{4}$

Regardless of whether they intended to ravage or to conserve natural resources, however, "permit systems were introduced by the colonial powers with the primary goal of dispossessing indigenous water users of their prior claims to water" (van Koppen, 2007:46). Writing about Tanzania, van Koppen notes that in the Water Ordinance of 1948 "water uses 'under native law and custom' were recognized but native users could only participate in decision making through 'duly authorized representatives'..." (van Koppen, 2007:54). Classic indirect rule as per Mamdani's description, in other words. In colonial Malawi, the Natural Resources Ordinance of 1952 introduced nationwide restrictions on African use of natural resources, including water. Specific rules were promulgated to control the sinking of wells and boreholes as well as opening gardens in water catchment areas (Mulwafu, 2011). Barbara van Koppen and others have noted the irony that the permit-based approach of Integrated Water IResource Management in recent times furthers these colonial-era policies, thereby intensifying the dispossession of informal small-scale water users (van Koppen, 2007, van Koppen, van der Zaag, Manzungu, \& Tapela, 2014, Franco et al., 2013).

Recent scholarship on water footprints and the flows of virtual water-both of which are indicators based on the water used in the production of traded goods-has sharply refocused attention on the vast global water asymmetries that have long outlived the age of empire (Allan, 2011; Allan, Keulertz, Soiamo, \& Warner, 2013; Hoekstra, 2009; Hoekstra, Chapagain, \& Zhang, 2016; Hoekstra \& Hung, 2002; Hoekstra \& Mekonnen, 2012, among others). The flows of blue, green, and gray water between affluent and destitute world regions pinpoint with precision the existing global relationships of power and the dimensions and directionality of "ecologically unequal trade" (Rodriguez-Labajos and Martinez-Alier 2015:544).

\section{I REFLECTIONS ON CLASS AND GENDER}

It goes without saying that a historical sensibility is necessary to the understanding of the contemporary lived experience of class in postcolonial Africa. Thus, for example, an analysis of class in the South African context needs to begin with the question of how apartheid worked as a system of labor control. Labor migrations were critical to the functioning and flourishing of race-inflected capitalism in South Africa (Hunter, 1936, Wolpe, 1972, Spiegel, 1980, van Onselen, 1982, Ferguson, 1990, Arrighi, Aschoff, \& Scully, 2010, etc.) and other parts (Arrighi, 1967, 1970) of what Samir Amin has described as the "Africa of the labour reserves" (Amin, 1976).

Scholarship in postcolonial South Africa points to the continuation of class inequality along the same well-worn grooves. Thus, Maharajh's economic history of racial capitalism documents the racial economic disparities that contemporary neoliberal South Africa has inherited from its apartheid past (Maharajh, 2011). Class inequalities are literally inscribed into the landscape — as in, for example, Lehohla and Shabalala's account of the social, economic, and spatial inequalities that are the legacy of 50 years of apartheid and 300 years of colonial rule in Africa (Lehohla \& Shabalala, 2014).

The continued segregation of residential areas of South African cities places black Africans, in particular, furthest away from the central business districts, making it difficult for them to access services such as water, hygiene, and sanitation. On the other hand, sewage systems and dumping sites are most often sited in areas where the poor reside (Robins, 2014). Swanson describes how Cape Town's urban poor, allegedly associated with the social and sanitary conditions that harbored the bubonic plague at the turn of the 20th century, were forcibly evicted from the central business district to the new settlement locations of Uitvlugt or Ndabeni which were also in the direction of odor from the city (Swanson, 1977). A similar situation happened in Johannesburg's Alexandra township, a predominantly black residential area which was established with barely any amenities. The intersection between class and race is more or less visible to the naked eye in an urban context. Du Plessis and Landman note that the spatial layout of the city has resulted in "the exclusion of large sections of the population from

${ }^{4}$ Smuts was the South African minister of defense from 1910 to 1919, and prime minister and minister of native affairs from 1919 to 1924 and 1939 to 1948 . He has been described as the "architect" of apartheid (Harvey, 2001:36-38). 
the economic, social and environmental benefits of vibrant, integrated, sustainable urban development" (Du Plessis \& Landman, 2002:2). The urban subalterns thus excluded range from the so-called dangerous classes to those that Bayat designates as "quiet rebels." The latter's politics of "quiet encroachment refers to the non-collective but prolonged direct action by individuals and families to acquire the basic necessities of their lives (land for shelter, urban collective consumption, informal jobs, business opportunities and public space) in a quiet and unassuming illegal fashion" (Bayat, 2000:536).

There is a sizeable literature that seeks to understand gender dynamics in postcolonial Africa within the context of everyday material struggles (e.g., Bay, 1982; Brownhill, 2009; Obbo, 1980). "From the colonial creation of the male breadwinner to contemporary contests over love and money", notes Andrea Cornwall, "the intersection of livelihoods and life ways forms a key thread through the literature on gender in Africa" (Cornwall, 2005:7). A recognition of material processes underpins, for example, Musisi's reflections on the colonial era construction of "good" and "bad" women in the emerging urban space of Kampala (Musisi, 2001). However, feminist economists have pointed out that gender continues to be sidelined in their field, not only by neoclassical economists, but surprisingly also by the Marxist tradition. Thus Shahra Razavi writes, "it is high time that the political economy of agrarian change acknowledged 'the other economy' of uncommodified work, domestic institutions and social relations" (Razavi, 2009:222).

This is critical since the experience of poverty and powerlessness is invariably gendered, as evidenced, for example, in Megan Vaughan's narration of famine in Malawi (Vaughan, 1987). Water poverty is also experienced in gendered ways, in Sub-Saharan Africa as it is elsewhere, with water-related tasks usually being assigned to women, while most water-related powers and rights remain with men (Magala, Kabonesa, \& Staines 2015; Hellum, Kameri-Mbote, \& van Koppen, 2015; UN, 2013). Even radical social transformation and the enactment of progressive legislation do not necessarily grant women access to or knowledge of their rights, as Mary Hames notes in the South African case (Hames, 2006). Moreover, progressive water policies may not go far enough — as in Loftus' discussion of the upheavals stemming from the limitations of the policy to provide free basic water to informal settlements in Durban. The gender division of labor means that women have to negotiate both a commoditized and a noncommoditized relationship to the work of water provisioning. He urges attention to the "situated knowledges of women as a necessary position for radical politics" (Loftus, 2009:965) - it is women's particular placement in daily struggles over water that sparks protests and offers new possibilities for democratic change.

\section{5 | A VIEW FROM MALAWI}

An edited volume by Guy Mhone, Malawi at the Crossroads: The Post-colonial Political Economy, appeared in 1992, the year that saw the most violent confrontation between the government and the populace since Malawi's independence from Britain in 1964. Drawing heavily on government sources, the contributors were still able to show that the country's "long term goals of economic growth, development and equity, have been sacrificed at the expense of private greed and aggrandisement by a minority political and economic elite" (Mhone, 1992: xviii). Most of them agreed that Malawi's economic difficulties were linked to the mismanagement and corruption rampant in President Kamuzu Banda's Malawi Congress Party (MCP) regime. This was about to change precisely at that juncture. By 1992, the Cold War had ended and the Soviet Union had collapsed. Reluctance to institute democratic reforms had estranged President Banda from his traditional Western donors, and also antagonized Malawians who were clamoring for a more open and accountable system of government. Pressure intensified on Banda when South Africa, Malawi's staunch ally, undertook to dismantle apartheid and create a multiparty democratic system, also in 1992. Demonstrations that year by university students and urban workers led to a referendum in June 1993 when Malawians overwhelmingly voted for change. This, in turn, paved the way for the May 1994 presidential elections in which Banda lost to his one-time MCP secretary-general, Bakili Muluzi, the leader of the United Democratic Front and a member of the minority Muslim community. At the time, a popularly held view was that the new political dispensation would promulgate laws and policies that would put an end or at least minimize the structural and socioeconomic inequalities created by Banda's political and economic elite.

An influential if controversial rebuttal to "dependency" perspectives, Bayart's notion of "extraversion" definitely comes to mind in the context of this volume (Bayart, 1993; Bayart \& Ellis, 2000), as also that which Englund describes as "chameleon politics," borrowing the image from a poem by Malawi's acclaimed writer Jack Mapanje (Englund, 2002). In Bayart's account, global geopolitics and Africa's marginalization become resources in their own right in the domain of African as well as global political cultures, as African political elites orient themselves outward and join "the rush for spoils in which all actors — rich and poor — participate in the world of networks" (Bayart, 1993:235). "Extraversion" has continued to be a notable feature in the regimes that followed Dr. Banda's- the concept returns as a theoretical pivot in an article by Brooks and Loftus on the recent politics of transition in Malawi (Brooks \& Loftus, 2016). Following Bayart, at a minimum, externally oriented and self-seeking postcolonial elites must not be regarded as an aberrant category, but as an enduring feature of class hierarchies. 
Present-day class conflicts in the countryside are determined, of course, by the historical structuring of land and labor in the Malawian context. An early contribution to the economic history of land tenure in Malawi by Bridglal Pachai considers migrations, settlement and competition for land in a society largely dominated by matrilineal inheritance (Pachai, 1978). To understand the conflict that dates back to the European land settlement, particularly after 1891, Pachai reviews such colonial era factors as the expansion of labor migration, the encouragement of tenant farming and cash crops, and the effect of the railway on land. Absentee landlords became an established feature as population increase exerted pressure on land and accelerated the move toward repurchase of freehold estates and systematic resettlement. Pachai reviews agricultural trends and land usage in the decade following independence, where the government became more concerned with the rights of the traditional majority. The Malawi Land Act of 1965 and subsequent legislation has sought to bring private, public, and customary land under uniform control to permit a more rational use of the nation's land resources (as much as $80 \%$ of the land was under customary tenure in 1974). More recently, the National Land Policy of 2002 and the newly enacted Land Laws of 2016 seek, among other things, to promote titling of land at an individual level. Customary land will be registered and individuals will be provided with private and unsufructory rights.

The anthropologist Pauline Peters has produced a body of work examining customary land tenure just as revisionist thinking in the World Bank and powerful aid agencies was beginning to cast these forms of landholding and land use favorably as "negotiable" and "adaptable" (Peters, 2004; Peters \& Kambewa, 2007). She found that new policies aiming to clarify and formalize customary forms of land tenure led to intensified competition over land even before they were implemented, setting in motion increased sales and rentals, but also new discourses about "original settlers" and "strangers," and political maneuvering by chiefs. Once in place, there was a further intensification of competition over land and a deepening of social differentiation in many realms - pitting young against old, men against women, and opening up confrontations along ethnic and religious lines. Most significantly for this discussion, these policies led to the appearance of new social divisions that could unmistakably be regarded as class formation.

A contrary note is sounded by Jul-Larsen and Mvula. Arguing that there is no evidence to support the view that agriculture plays a role in the formation of wealth and elites at either the local or the national level, they observe that elite status in Malawi (and elsewhere in Africa) is in fact a function of access to state power and resources. "In the context of customary tenure", they conclude that "the egalitarian and communal ideologies and values that underlie customary law are sometimes a bulwark against the accumulation of land and increased economic differentiation" (Jul-Larsen \& Mvula, 2009:189). The land reform process begun with the Land Bill of 2016 has not settled this debate.

\section{6 | COLONIAL POLICIES AND WATER CONFLICTS IN MALAWI}

Wapulumuka Mulwafu's, 2011 book Conservation Song considers the agriculture-dependent economy of Malawi, the ecological impact of agrarian policies and the political impact of state-enforced conservation measures, both in colonial and postcolonial times.

The establishment of British rule in the late 19th century brought a familiar pattern of changes to the countryside- the production of commercial crops such as cotton, maize, tea, and tobacco; an increase in rural poverty, inequality and landlessness; the setting up of estates and native reserves. By the 1920s, this had led to significant ecological damage, considerable soil erosion and falling agricultural yields. Concerned at the extent of land degradation, the colonial government introduced in the 1930s another set of policies, malimidwe (conservation measures), to restore the soil.

The controversial malimidwe measures implemented by the British in the 1930s - the planting of grasses and trees to protect watersheds, the construction of structures to prevent soil erosion, etc.- - were probably quite sound from a soil conservation standpoint, even if they showed no interest in or regard for existing local conservation practices. However, they were also extremely labor intensive, and the imposition of compulsory labor requirements (thangata) for their construction meant that there were labor shortages at crucial stages of the agricultural cycle. These resentments about compulsory labor exploded into protests, which were violently suppressed by the British. Mulwafu describes the politicization of women, the main agricultural workers, in this process. Protests against malimidwe fed into the decolonization movement, leading finally to Malawi's independence in 1964.

It may seem curious at first sight that colonial soil conservation policies should develop into a major flashpoint in just the same way as oppressive colonial revenue demands or colonial policies of racial discrimination. The central issue, of course, was the compulsory nature of the labor demands forced on to an already overburdened peasantry. Mulwafu's work points to the explosive political potential of high-handed colonial policies regarding natural resources, and shows us that postcolonial policies regarding resource conservation and distribution can equally stoke fierce resentments. Conservation Song is set in an environment of competing interests for control of natural resources along racial and class lines. It provides an entry point for understanding the impetus for policy development and practices in postcolonial Malawi. At the same time, 
it decries the lack of serious attention to historical perspectives regarding many of the environmental issues facing the country. The desire for quick fixes to environmental problems ignores existing historical knowledge about local systems and previous interventions.

Another historical example that touches directly on issues of water and colonialism was the predicament faced by the inhabitants of the Lake Chilwa Basin in Malawi who had to contend with a dual crisis in the 1930s - the drying up of Lake Chilwa and the knock-on effects of the Great Depression. Fisheries collapsed and there were limited alternative employment possibilities in Rhodesia and South Africa due to the global economic crisis. To combat the shortfall in its export income and tax revenues, the colonial government began to insist that locals should cultivate cotton on the wetland exposed by the receding lake (Nagoli, Green, Mulwafu, \& Chiwona-Karltun, 2017). Nagoli et al. observe that the locals subverted this by roasting or boiling the cotton seeds before planting them. This is yet another example of colonized groups successfully managing to withstand official policy even as they found new ways to cope with water scarcity (hunting birds after the collapse of the fisheries, for example).

The intertwining of land, water, and irrigation policies in Malawi does make it necessary to examine water in the context of natural resources in general (Ferguson \& Mulwafu, 2004). This is evident in Ferguson and Mulwafu's discussion of the transfer of government-run irrigation schemes to farmers' associations, an important element of neoliberal reform, which has made small farmers' land and water rights less secure than before (Ferguson \& Mulwafu, 2007). In principle, the transfer sought to empower the small-scale farmer by having them manage the irrigation schemes and increase their income, but in practice, farmers have been burdened with numerous challenges including inheritance of dilapidated structures. The process has also resurrected age-old tensions regarding land ownership, whereby prescheme occupants have been claiming their rights to the land and water.

\section{I WATER ACCESS IN POSTCOLONIAL MALAWI}

The history of colonial-era ecological conflicts holds important lessons for the politics of water in present-day Malawi. The neglect of water poverty that has continued into the postcolonial era has given rise to serious challenges in the form of uncoordinated and small-scale direct action by the downtrodden classes. The hidden acts of resistance such as illegal disconnections and the cutting of distribution pipes point to a larger problem of inequalities in water distribution. As in South Africa and, indeed many other African countries, Malawi's urban waste disposal system militates against the poor. In Lilongwe, Zomba, and Mzuzu, for instance, the waste dumping sites are located closer to low income residential areas. Ironically, these are also areas with poor access to water and sanitation services. A potentially volatile situation has been created where community struggles over health and environment are likely to interlace with broader claims over economic justice and class politics.

Inequalities in access to water create opportunities for political patronage and manipulation. This is particularly reflected in the areas of water provision and pricing. Water provision has become a highly contested issue in postcolonial Malawi. Fundamentally, the challenge comes from the fact that availability and distribution of water is uneven across space and class. Although access to safe drinking water has been increasing over the years, having gone up to $86.5 \%$ by 2014 (GOM, 2014), issues of quality, reliability of supply systems, and affordability remain skewed across class and space. The adoption of a decentralized system of water supply in the 1990s opened up space for different interest groups to start flexing their muscles with respect to the resource. The role of central government has further been diminished by lack of financial and human resources to effectively monitor the performance of different stakeholders. The result is that at times providers supply water not because they want to meet the needs of poor people but simply to enhance their position and influence. During election campaigns, water features prominently as a hotly contested issue, since the provision of water immediately earns the support of the electorate. For example, in the run-up to the 1999 election, President Muluzi promised to drill over 3,000 boreholes across the country. Financial resources were subsequently mobilized and several drilling companies were established to facilitate the provision. However, barely 3 years after installation, less than half of the boreholes were found to be functional (DeGabriele, 2002; Transparency International, 2008). In an earlier study which examined issues that dominated parliamentary debates in Malawi between 1994 and 1998, water topped the list (Banda \& Mulwafu, 1998).

Owing to the technical nature of the water works involved, it is not easy for the average person to understand and this creates room for corruption. A survey of the corruption perceptions index for 2007 by Transparency International showed that Malawi ranked 118 out of 180 countries. The report showed that in many villages, expensive drilling equipment was being used where cheaper technologies could have been used considering that the water table was relatively high (Transparency International, 2008:46). The recent financial scandal dubbed "cashgate," where about US\$ 50 million were plundered from state coffers between 2012 and 2013 also included the water sector (Baker Tilly Business Services Ltd, 
2013). Water has become a resource imbued with corruption at different levels of society, increasingly appearing in the limelight because competing interests seek to use water for political patronage.

Water providers have also carved out what one may call spheres of influence. Currently, key players in water provision include NGOs, politicians and the private sector. Depending on the source of funding, some NGOs have been working in designated areas where other NGOs find it difficult to operate. This division takes the form of religion, political affiliation, or nationality of the provider.

Political patronage also plays a role in water pricing. Under the Water Works Act of 1995, five utility organizations are responsible for provision of water in urban areas. They treat the water and distribute it to different consumers on a commercial basis (GOM, 1995). The tariff structure recognizes water for the poor and penalizes large-scale consumers of water as a demand management strategy (GOM, 2013). The setting of water prices is highly contested, however, since the government often intervenes in the process, especially during election campaigns. Despite the rising costs of treating and providing water to consumers, no government wishes to be seen to be burdening the electorate just as it is preparing to go to the polls. Originally set up to be self sustaining economic entities, water utility organizations can no longer function as such due to these frequent government interventions as well as small acts of resistance from water users. The Nation newspaper of October 25, 2017 reported, for example, that Lilongwe Water Board loses about K4 billion in nonrevenue water due to illegal connections, leakages, and nonpayment of water bills.

Another important line of investigation into the distribution of water in postcolonial Malawi is the interesting recent research on the variability of drinking water quality in Lilongwe, which recognizes that quality is a critical dimension of access to water. Interweaving biophysical and sociopolitical analyses of variations in water quality, this work is extending urban political ecology in productive new directions (Rusca, Boakye-Ansah, Loftus, Ferrero, \& van der Zaag, 2017).

\section{I CONCLUSION}

Some readers may question our decision to delve into colonial era environmental history as we attempt to understand contemporary struggles over water. Everything that needs to be said about governance in the age of empire has already been said, they will argue. Also, it was all so long ago_does it still matter now? As it happens, we are writing in a particularly unsettled moment for the debates over the legacies of colonialism. Discourses of imperial redemption and nostalgia are on the rise, coursing through the pronouncements of prominent scholars like Niall Ferguson, Bruce Gilley, and Nigel Biggar. Under these circumstances, what is needed are more, rather than less, appraisals of colonial governance in concrete realms, such as its approach toward natural resources, including water. Colonial rule is an inalienable part of the relatively recent history of many African nations. When considering the history of water poverty in Malawi, it would be perverse to arbitrarily stop short of the colonial era or to refuse to examine its continuities with present-day relationships of power in relation to water. Certainly no such statute of limitations is ever enjoined upon those charting the histories of natural resources in regions that did not experience colonial rule. Given that "water often does lie at the very heart of the complexity of social and historical concerns that form the focus of our disciplines" (Fontein, 2008:738), it works as an extraordinarily significant conceptual device for understanding the colonial experience and its continuing impact on postcolonial societies. Accordingly, we have sought insights about water conflicts from analyses of colonialism and its aftermath, while remaining attuned to colonial dynamics and histories within studies of water, in the hope that these forays across literatures and disciplines will provoke useful conversations. .

\section{ACKNOWLEDGMENTS}

We wish to thank Dr. Tracy Morse (University of Strathclyde/University of Malawi) for providing the photograph that accompanies this essay. Our essay draws significantly on the report on the influence of conflict, gender and class relations on water availability (Deliverable 5.1) written for the EU Horizon 2020 funded WATERSPOUTT (Water-Sustainable Point of Use Treatment Technologies) research project. Prof. Honor Fagan, WATERSPOUTT Social Science Work Package leader, and Dr. Daniel Etongo Bau, both based at the National University of Ireland, Maynooth, read and commented on numerous drafts of the report, and contributed substantially to its improvement. We are extremely grateful for the extensive bibliographic advice received from these colleagues in the four African WATERSPOUTT partner institutions-Dr. Consolata Kabonesa and Dr Richard Asaba at Makerere University in Uganda; Dr. Zenawi Zerihun, Dr Kelemework Tafere Reda and Mr. Zena Zedo at Mekelle University in Ethiopia; Mr. Berry Wessels at the Sustainability Institute at the University of Stellenbosch in South Africa; and Dr. Tracy Morse, Dr. Levison Chiwaula and Mr. Sothin Zibah at the University of Malawi. We also wish to thank our Europe-based WATERSPOUTT social science colleagues, Professor Michelle Kooy of UNESCO-IHE Delft in the Netherlands and Dr. George Clerk of Buckinghamshire New University in the UK, for their 
advice and encouragement. Finally, we owe thanks to this journal's anonymous reviewers for their careful reading and constructive feedback.

\section{CONFLICT OF INTEREST}

The authors have declared no conflicts of interest for this article.

\section{RELATED WIRES ARTICLES}

Climate and history: a critical review of historical climatology and climate change historiography

My pipes say I am powerful: belonging and class as constructed through our sewers

Local control: authority, resistance, and knowledge production in fracking

Political ecology of water conflicts

\section{REFERENCES}

Allan, J. A. (2011). Virtual water: Tackling the threat to our planet's most precious resource. London, England: I. B. Tauris.

Allan, J. A., Keulertz, M., Soiamo, S., \& Warner, J. (Eds.). (2013). Handbook of land and water grabs in Africa: Foreign direct investment and food and water security. London, England: Routledge.

Amin, S. (1976). An essay on the social formations of peripheral capitalism. New York, NY: Monthly Review Press.

Arrighi, G. (1967). The political economy of Rhodesia. The Hague, The Netherlands: Mouton.

Arrighi, G. (1970). Labor supplies in historical perspective: A study of the proletarianization of the African peasantry in Rhodesia. Journal of Development Studies, 6(3), 197-234.

Arrighi, G., Aschoff, N., \& Scully, B. (2010). Accumulation by dispossession and its limits:The southern Africa paradigm revisited. Studies in Comparative International Development, 45, 410-438.

Baker Tilly Business Services Ltd. (2013). National Audit Office of Malawi: “Cashgate” A summary report on the findings arising from work carried out into Fraud and Mismanagement of Malawi Government Finances.. London: Baker Tilly Risk Advisory Services LLP. https://issuu.com/npl8/docs/cashgate_national_audit_ office_of_m

Bakker, K. (2004). An uncooperative commodity: Privatising water in England and Wales. Oxford, England: Oxford University Press.

Banda, J., \& Mulwafu, W. O. (1998). Evaluation of the Malawi Parliamentary Training Programme, Unpublished Report for UNESCO. Zomba: National Assembly of Malawi.

Bay, E. G. (Ed.). (1982). Women and work in Africa. Boulder, CO: Westview.

Bayart, J.-F. (1993). The state in Africa: The politics of the belly. London, England: Longman.

Bayart, J.-F., \& Ellis, S. (2000). Africa in the World: A History of Extraversion. African Affairs., 99(395, Centenary Issue: A Hundred Years of Africa), 217-267.

Bayat, A. (2000). Dangerous classes' to 'quiet rebels': Politics of the urban subaltern in the global south. International Sociology, 15 (3), 533-557.

Beinart, W. (2000). African history and environmental history. African Affairs, 99, 269-302.

Berry, S. (1992). Hegemony on a shoestring: Indirect rule and access to agricultural land. Africa: Journal of the International African Institute, 62(3), 327-355.

Brooks, A. R., \& Loftus, A. J. (2016). Africa's passive revolution: Crisis in Malawi. Transactions of the Institute of British Geographers, 41, 258-272. https://doi. org/10.1111/TRAN.12120

Brownhill, L. (Ed.). (2009). Land, food, freedom: Struggles for the gendered commons in Kenya, 1870-2007. Trenton, NJ: Africa World Press.

Bryant, R., \& Bailey, S. (Eds.). (1997). Third world political ecology. New York, NY: Routledge.

Carmody, P. (2011). The new scramble for Africa. Cambridge, England: Polity Press.

Chanock, M. (1985). Law, custom and social order: The colonial experience in Malawi and Zambia. Cambridge, England: Cambridge University Press.

Cooke, B. (2003). A new continuity with colonial administration: Participation in development management. Third World Quarterly, 24(1), 47-61.

Cornwall, A. (Ed.). (2005). Readings in Gender in Africa. Bloomington, IN: Indiana University Press.

Davidson, B. (1980). The African slave trade. Boston, MA: Little, Brown and Company.

DeGabriele, J. (2002). Improving community based management of bore holes: A case study from Malawi (Final Research Report). BASIS CRSP, Madison, WI. http://pdf.usaid.gov/pdf_docs/Pnacp702.pdf

Donahue, J., \& Johnston, B. R. (Eds.). (1997). Water, culture and power: Local struggles in a global context. Washington, DC: Island Press.

Du Plessis, C., \& Landman, K. (2002). Sustainability analysis of human settlements in South Africa. Pretoria, South Africa: CSIR Building and Construction Technology.

Englund, H. (Ed.). (2002). A democracy of chameleons: Politics and culture in the new Malawi. Elanders Gotal: Stockholm, Sweden.

Ferguson, A. \& Mulwafu, W.O. (2004) Irrigation reform on Malawi's Domasi and Likangala smallholder irrigation schemes: Exploring land-water intersections (Final Research Report). BASIS CRSP, Madison, WI. http://pdf.usaid.gov/pdf_docs/Pnade775.pdf

Ferguson, A., \& Mulwafu, W. O. (2007). If government failed, how are we to succeed?: The importance of history and context in present-day irrigation reform in Malawi. In B. Van Koppen, M. Giordano, \& J. Butterworth (Eds.), Community based water law and water resources management reform in developing countries Comprehensive Assessment of Water Management in Agriculture Series 5 (pp. 211-227). Wallingford, England: CAB International.

Ferguson, J. (Ed.). (1990). The anti-politics machine: "Development", depoliticization and bureaucratic power in Lesotho. Cambridge, England: Cambridge University Press.

Fontein, J. (2008). The power of water: Landscape, water and the state in southern and eastern Africa: An introduction. Journal of Southern African Studies, 34(4), $737-756$.

Foster, J. B., \& Clark, B. (2008). The sociology of ecology: Ecological organism versus ecosystem ecology in the social construction of ecological science, 1926-1935. Organisation and Environment, 21(3), 311-352.

Franco, J., Mehta, L., \& Veldwisch, G. J. (2013). The global politics of water grabbing. Third World Quarterly, 34(9), 1651-1675.

GOM. (1995). Government of Malawi, Waterworks Act, No. 17 of 1995, Retrieved from http://www.malawilii.org/mw/legislation/num-act/1995/17/numact199517.pdf

GOM. (2013). National water resources act. Lilongwe, Malawi: Ministry of Irrigation and Water Development. 
GOM. (2014). Millenium development goals endline report. Lilongwe, Malawi.

Grove, R. H. (1995). Green imperialism: Colonial expansion, Tropical Island Edens and the origins of environmentalism, 1600-1860. Cambridge, England: Cambridge University Press.

Guelke, L., \& Shell, R. (1992). Landscapes of conquest: Frontier water alienation and Khoikhoi strategies of survival, 1652-1780. Journal of Southern African Studies, $18(4), 803-824$.

Hames, M. (2006). Rights and realities: Limits to Women's rights and citizenship after 10 years of democracy in South Africa. Third World Quarterly, 27(7), $1313-1327$

Harvey, D. (1982). The limits to capital. Oxford, England: Blackwell.

Harvey, D. (2003). The new imperialism. Oxford, England: Oxford University Press.

Harvey, R. (Ed.). (2001). The fall of apartheid: The insider story from smuts to Mbeki. New York, NY: Palgrave.

Hastrup, K. B., \& Hastrup, F. (2015). Waterworlds: Anthropology in fluid environments Ethnography, theory, experiment (Vol. 3). Oxford, England: Berghahn Books.

Hellum, A., Kameri-Mbote, P., \& van Koppen, B. (Eds.). (2015). Water is life: Women's human rights in national and local water governance in southern and eastern Africa. Harare, Zimbabwe: Weaver Press.

Hobsbawm, E., \& Ranger, T. (Eds.). (1984). The invention of tradition. Cambridge, England: Cambridge University Press.

Hoekstra, A. Y. (2009). Human appropriation of natural capital: A comparison of ecological footprint and water footprint analysis. Ecological Economics, 2009(68), 1963-1974.

Hoekstra, A. Y., Chapagain, A. K., \& Zhang, G. (2016). Water footprints and sustainable water allocation. Sustainability, $2016(8), 20$.

Hoekstra, A.Y. \& Hung, P.Q. (2002). Virtual water trade: A quantification of virtual water flows between nations in relation to international crop trade (UNESCO-IHE Value of Water Research Report Series). Delft, The Netherlands: IHE.

Hoekstra, A. Y., \& Mekonnen, M. M. (2012). The water footprint of humanity. Proceedings of the National Academy of Sciences of the United States of America, 109, 3232-3237.

Hunter, M. (1936). Reaction to conquest. London, England: Oxford University Press.

Johnston, B. R. (2003). The political ecology of water: An introduction. Capitalism Nature Socialism, 14(3), 73-90.

Jul-Larsen, E., \& Mvula, P. (2009). Security for many or surplus for the few? Customary tenure and social differentiation in southern Malawi. Journal of Southern African Studies, 35(1), 175-190.

van Koppen, B. (2007). Dispossession at the Interface of community-based water law and permit systems. In B. Van Koppen, M. Giordano, \& J. Butterworth (Eds.), Community-based water law and water resource management reform in developing countries (pp. 211-227). CABI Publishing.

Lehohla, P., \& Shabalala, N. (2014). Inequality in South Africa. Development, 57(3-4), 497-511.

Loftus, A. (2009). Rethinking political ecologies of water. Third World Quarterly, 30(5), 953-968.

Luxemburg, R. (1913). The Accumulation of Capital, reprinted (2003). Abingdon, England: Routledge Classics.

Magala, J. M., Kabonesa, C., \& Staines, A. (2015). Women and water politics: An ethnographic gender perspective. In R. Munck, N. Asingwire, G. H. Fagan, \& C. Kabonesa (Eds.), Water and development: Good governance after neoliberalism, Chapter Eight, Part Two. (pp. 172-180). London, England: Zed Books.

Maharajh, R. (2011). Innovating beyond racial capitalism: A contribution towards the analysis of the political economy of post-apartheid South Africa. Lund Studies in Research Policy 3. Lund, Sweden: Lund University.

Mamdani, M. (1996). Citizen and subject: Contemporary Africa and the legacy of late colonialism. Princeton, NJ: Princeton University Press.

Mehta, L., Veldwisch, G. J., \& Franco, J. (2012). Introduction to the special issue: Water grabbing? Focus on the (re)appropriation of finite water resources. Water Alternatives, 5(2), 193-207.

Mhone, G. (Ed.). (1992). Malawi at the crossroads: The post-colonial political economy. Harare, Zimbabwe: SAPES.

Mills, D. (2006). How not to be a "government house pet": Audrey Richards and the east African Institute for Social Research. In M. Ntarangwi, D. Mills, \& M. Babiker (Eds.), African anthropologies: History, critique and practice. New York, NY: Zed Books.

Mintz, S. (1985). Sweetness and power: The place of sugar in modern history. New York, NY: Viking-Penguin.

Mizuno, N., \& Okazawa, R. (2009). Colonial experience and postcolonial underdevelopment in Africa. Public Choice, 141, 405-419.

Mulwafu, W. O. (2011). Conservation song: A history of peasant-state relations on the environment in Malawi, 1,860-2000. Cambridge, England: The White Horse Press.

Musisi, N. B. (2001). Gender and the cultural construction of "bad women" in the development of Kampala-Kibuga, 1900-1962. In D. L. Hodgson \& S. A. McCurdy (Eds.), "Wicked" women and the reconfiguration of gender in Africa. Portsmouth, NH: Heinemann.

Nagoli, J., Green, E., Mulwafu, W. O., \& Chiwona-Karltun, L. (2017). Coping with the double crisis: Lake Chilwa recession and the great depression on Chisi Island in colonial Malawi, 1930-1935. Human Ecology, 45(1), 111-117.

Naqvi, N., \& Mathur, C. (2001). After colonialism: An interview with Mahmood Mamdani. SAMAR, 13, 24-28.

Obbo, C. (1980). African women: Their struggle for economic independence. London, England: Zed Books.

Orlove, B., \& Caton, S. (2010). Water sustainability: Anthropological approaches and prospects. Annual Review of Anthropology, 39, 401-415.

Pachai, B. (Ed.). (1978). Land and politics in Malawi, 1,875-1975. Kingston, Canada: Limestone Press.

Pakenham, T. (1991). The scramble for Africa, 1,876-1912. London, England: Weidenfeld and Nicholson.

Peet, R., Robbins, P., \& Watts, M. (Eds.). (2010). Global political ecology. New York, NY: Routledge.

Peet, R., \& Watts, M. (Eds.). (2004). Liberation ecologies. New York, NY: Routledge.

Peters, P. (2004). Inequality and social conflict over land in Africa. Journal of Agrarian Change, 4(3), 269-314.

Peters, P., \& Kambewa, D. (2007). Whose security? Deepening social conflict over 'customary' land in the shadow of land tenure reform in Malawi. The Journal of Modern African Studies, 45(3), 447-472.

Razavi, S. (2009). Engendering the political economy of agrarian change. The Journal of Peasant Studies, 36(1), 197-226.

Richards, A. I. (Ed.). (1954). Economic development and tribal change: A study of immigrant labour in Buganda. Cambridge, England: East African Institute of Social Research by W. Heffer and Sons Ltd.

Robins, S. (2014). Poo wars as matter out of place: 'Toilets for Africa' in cape town. Anthropology Today, 30, 1-3. https://doi.org/10.1111/1467-8,322.12081

Rodríguez-Labajos, B., \& Martínez-Alier, J. (2015). Political ecology of water conflicts. WIREs Water, 2, 537-558. https://doi.org/10.1002/wat2.1092

Rusca, M., Boakye-Ansah, A. S., Loftus, A., Ferrero, G., \& van der Zaag, P. (2017). An interdisciplinary political ecology of drinking water quality: Exploring socio-ecological inequalities in Lilongwe's water supply network. Geoforum, 84, 138-146. https://doi.org/10.1016/j.geoforum.2017.06.013

Southall, A. (1970). The illusion of tribe. Journal of African and Asian Studies, 5, 28-50.

Spiegel, A. (1980). Changing patterns of migrant labour and rural differentiation in Lesotho. Social Dynamics, 6(2).

Strang, V. (2004). The meaning of water. London, England: Berg.

Strang, V. (2009). Gardening the world: Agency, identity, and the ownership of water. Oxford, England: Berghahn Publishers.

Swanson, M. (1977). The sanitation syndrome: Bubonic plague and urban native policy in the cape Colony, 1900-1909. The Journal of African History, 18. 
Swyngedouw, E. (2003). Privatising H2O: turning local water into global money. Journal fur Entwicklungspolitik, 19(4), 10-33.

Transparency International. (2008). Global corruption report 2008: Corruption in the water sector. Cambridge, England: Cambridge University Press.

UN. (2013). Women and agricultural water resource management. Retrieved from http://unchronicle.un.org/article/women-and-agricultural-water-resource management/

United Nations Development Programme (UNDP). (2006). Human development report 2006 - beyond scarcity: Power poverty and the global water crisis. Oxford, England: Oxford University Press.

van Koppen, B., van der Zaag, P., Manzungu, E., \& Tapela, B. (2014). Roman water law in rural Africa: The unfinished business of colonial dispossession. Water International, 39(1), 49-62.

van Onselen, C. (1982). Social and economic history of the Witswatersrand, 1886-1914 (Vol. 1 \& 2). Johannesburg, South Africa: Ravan Press.

Vaughan, M. (1987). The story of an African famine: Gender and famine in twentieth century Malawi. Cambridge, England: Cambridge University Press.

WaMuiu, M. (2010). Colonial and postcolonial state and development in Africa. Social Research: An International Quarterly, 77(4), 1311-1338.

Wittfogel, K. A. (1957). Oriental despotism: A comparative study of Total power. New Haven, CT: Yale University Press.

Wolf, E. R. (1982). Europe and the people without history. Berkeley: University of California Press.

Wolpe, H. (1972). Capitalism and cheap labour-power in South Africa: From segregation to apartheid. Economy and Society, 1(4), 425-455.

How to cite this article: Mathur C, Mulwafu W. Colonialism and its legacies, as reflected in water, incorporating a view from Malawi. WIREs Water. 2018;e1287. https://doi.org/10.1002/wat2.1287 